\title{
Use of the intertidal zone by mobile predators: influence of wave exposure, tidal phase and elevation on abundance and diet
}

\author{
A. C. F. Silva ${ }^{1,2, *}$, S. J. Hawkins ${ }^{2,3}$, D. M. Boaventura ${ }^{4,5}$, E. Brewster ${ }^{1}$, R. C. Thompson ${ }^{1}$ \\ ${ }^{1}$ Marine Biology \& Ecology Research Group, University of Plymouth, Drake Circus, Plymouth PL4 8AA, UK \\ ${ }^{2}$ Marine Biological Association of the United Kingdom, Citadel Hill, Plymouth PL1 2PB, UK \\ ${ }^{3}$ School of Ocean Sciences, Bangor University, Menai Bridge, Ynys Mon LL59 5AB, UK \\ ${ }^{4}$ Escola Superior de Educação João de Deus, Av. Álvares Cabral 69, Lisboa 1269-094, Portugal \\ ${ }^{5}$ Laboratório Marítimo da Guia, Estrada do Guincho, 2750-374 Cascais, Portugal
}

\begin{abstract}
Linkages between predators and their prey across the subtidal-intertidal boundary remain relatively unexplored. The influence of tidal phase, tidal height and wave exposure on the abundance, population structure and stomach contents of mobile predatory crabs was examined on rocky shores in southwest Britain. Crabs were sampled both during the day and at night using traps deployed at high tide and by direct observation during low tide. Carcinus maenas (L.), Necora puber (L.) and Cancer pagurus (L.) were the most abundant species, being mainly active during nocturnal high tides. C. maenas was the only species that was active during nocturnal low tides, when it was observed mainly on the lower shore feeding on limpets. Individuals of all 3 species sampled during high tide were considerably larger than those sampled during low tide. Thus, sampling crab populations at low tide is likely to underestimate abundance and the extent of predation by crabs on rockyshore assemblages. During immersion, the relative abundance of each species was influenced by exposure to wave action and tidal elevation. All species were more abundant on the lower shore, C. maenas and $N$. puber were more abundant in sheltered locations, while C. pagurus was more abundant in exposed locations. Analyses of stomach contents from individuals captured at high tide revealed that chitons and limpets were the most common hard-shell prey taxa in the diet of these predators. The relative abundance of prey in gut contents was, however, not correlated with patterns of prey abundance. Our study indicates the importance of crabs as key intertidal predators and illustrates the strong trophic linkages between the subtidal and intertidal zones, which is likely to be a key factor influencing community structure on European shores.
\end{abstract}

KEY WORDS: Wave action $\cdot$ Shore level $\cdot$ High and low tide $\cdot$ Crab $\cdot$ Population structure $\cdot$ Stomach contents $\cdot$ Prey abundance

Resale or republication not permitted without written consent of the publisher

\section{INTRODUCTION}

Existing models of intertidal community structure (Menge \& Sutherland 1976, Menge 1978a, b, Menge et al. 1999, 2002, 2003) have contributed much to several ecological theories. They have, however, emphasised the role of more sedentary consumers; the role of highly mobile predators is much less well understood. Thus, knowledge about the numbers of mobile predators, and information about where, when and on what they for- age is crucial to our understanding of predator-prey dynamics. Movement patterns determine the abundance and distribution of predators such as crabs and are influenced by the interaction of physical and biological factors (see Menge 2000). Previous observations on rocky shores in the northwest Atlantic and Pacific have shown that decapods are predominately active during high tide and indicate that biological factors such as prey distribution (Robles et al. 1990, Jones \& Shulman 2008) and physical factors including refuge 
availability (Lohrer et al. 2000, Holsman et al. 2006) influence spatial patterns of distribution for crabs. There is evidence that mobile species such as crabs and lobsters undertake substantial incursions from the sublittoral into the intertidal zone of Pacific coasts during high tide (e.g. Robles et al. 1990, Rilov \& Schiel 2006b). It has been suggested that this is to access additional food resources, and because crabs move mainly at night, this may minimise vulnerability from exclusively sublittoral predators including fish (e.g. Hughes \& Seed 1995, Burrows et al. 1999, Rilov \& Schiel 2006b, Jones \& Shulman 2008). These studies suggest that considerable trophic connectivity exists between the sublittoral and littoral habitats.

Knowledge of the extent and significance of the connectivity between the subtidal and intertidal zones, its strength, the species involved and the factors causing variation in this linkage is essential to a more comprehensive understanding of coastal food webs and ecosystems. For instance, the abundance of intertidal prey varies along environmental gradients of tidal elevation and exposure to wave action (Lewis 1964, Raffaelli \& Hawkins 1996). These gradients also determine the duration and suitability of various foraging windows (high and low tide, day and night) for predation (e.g. Boulding et al. 1999, Faria \& Almada 2006, Hollingsworth \& Connolly 2006), and can also affect predator behaviour (e.g. Menge 1978b, Menge \& Sutherland 1987), both directly by impeding prey handling, or indirectly by influencing prey abundance. Other factors such as habitat seascapes are an important influence on the distribution of mobile predators in the intertidal zone during high tide (see Rilov \& Schiel $2006 a, b)$. There is relatively little information on factors influencing the distribution of mobile predatory crabs on rocky shores of the northeast Atlantic, and most of the information available pertains to Carcinus maenas (e.g. Naylor 1958, 1962, Hughes \& Elner 1979, Kaiser et al. 1990, Warman et al. 1993, Burrows et al. 1999, Mascaró \& Seed 2001, Moksnes 2004) and semiterrestrial species such as Pachygrapsus marmoratus (e.g. Cannicci et al. 1999, 2002, Flores \& Paula 2001).

The distribution of these crabs is influenced by prey distribution and by the tidal cycle. For example, Carcinus maenas has been observed to regularly forage in the intertidal zone during nocturnal high tide (Hunter \& Naylor 1993, Burrows et al. 1999), as have semiterrestrial crabs such as grapsids during nocturnal low tides (Cannicci et al. 2002, Silva et al. 2004, 2009). Barnacles, mussels and limpets are an important part of the diet of Carcinus maenas (Hughes \& Elner 1979, Elner 1981, Kaiser et al. 1993) and Pachygrapsus marmoratus (Cannicci et al. 2002). For some common and commercially important species such as Necora puber and Cancer pagurus, patterns of abundance in the intertidal are less well understood (but see Norman \& Jones 1990, Karlsson \& Christiansen 1996, Lee et al. 2006) and, hence, the extent of their role in the dynamics of intertidal systems is not clear.

Some intertidal crabs (e.g. Carcinus maenas, Pachygrapsus spp.) are capable of withstanding substantial periods of exposure to air (Newell et al. 1972) by aerating the water around their gills, or using branchial chambers to function like lungs (Warner 1977), potentially enabling foraging during low tides. Ontogenetic stage and sex have also been reported to influence crab distribution (Moksnes 2002, Pardo et al. 2007, Spooner et al. 2007), behaviour (Mascaró \& Seed 2001, Spooner et al. 2007) and diet (Kaiser et al. 1993, Brousseau et al. 2001, Bishop \& Wear 2005). In situ observations of crab feeding behaviour are difficult to obtain (but see Burrows et al. 1999); however, stomach contents have been widely used to indicate crab diet (e.g. Williams 1981, Freire 1996, Cannicci et al. 2002).

In the present study, we quantified the intensity of the subtidal-intertidal trophic linkage established by crabs on European shores, within the framework of environmental gradients such as wave action and immersion, which are known to influence community structuring on rocky shores (see Robles et al. 1990, Thompson et al. 2004). We characterised the size, sex and abundance of juvenile and adult individuals captured on shores of differing wave exposure and tidal heights during low and high tides. Stomach contents were used to establish the importance of hard-shelled prey (e.g. topshells and limpets) in the diet of crabs captured in the intertidal zone at high tide so as to relate the abundance of prey in the stomach to the prey's distribution on the shore. We tested the general hypothesis that there are strong trophic linkages between the subtidal and intertidal zones. We also tested the following specific null hypotheses: (1) there are no differences in the species composition and abundance of crabs with exposure to wave action and tidal height; (2) there are no differences in the relative abundance and size of crabs in the intertidal zone between high and low tide; (3) there are no differences in the stomach-content composition of these predators between sexes and ontogenetic stages (juvenile and adult); and (4) there is no relationship between the relative abundance of hard-shelled prey and the abundance in the guts of crabs.

\section{MATERIALS AND METHODS}

Study sites. Two moderately exposed (Thurlestone: $50^{\circ} 15^{\prime} \mathrm{N}, 35^{\circ} 1^{\prime} \mathrm{W}$ and Portwrinkle: $50^{\circ} 21^{\prime} \mathrm{N}, 4^{\circ} 18^{\prime} \mathrm{W}$ ) and 2 moderately sheltered rocky shores (Mount Batten: $50^{\circ} 21^{\prime} \mathrm{N}, 4^{\circ} 07^{\prime} \mathrm{W}$ and Jennycliff: $50^{\circ} 21^{\prime} \mathrm{N}, 4^{\circ} 07^{\prime} \mathrm{W}$ ), 
hereinafter referred to as exposed and sheltered shores, were examined (Fig. 1). These shores were randomly selected from a range of suitable shores in southwest Britain and are representative of other shores in the region. At each shore 2 sites were sampled, allowing tests of variation in the abundance of predators at large $(\mathrm{km})$ and small $(\mathrm{m})$ spatial scales.

Levels of exposure to wave action were confirmed using measures of mean flow conditions following Jonsson et al. (2006), via the dissolution of gypsum $\left(\mathrm{CaSO}_{4}\right)$ discs. Sets of 12 discs were attached to the rock surface $\sim 3 \mathrm{~m}$ above chart datum (CD) for a single high tide on each of 2 occasions at each location. Discs on exposed shores dissolved significantly $(p<0.04)$ faster $\left(6 \mathrm{~g} \mathrm{~h}^{-1}\right)$ than on more sheltered shores $\left(2 \mathrm{~g} \mathrm{~h}^{-1}\right)$, giving a clear separation of exposure between locations. There were no significant differences $\left(F_{1,24}=\right.$ 34.6, p > 0.1) between shores within exposures (Thurlestone: $5.8 \mathrm{~g} \mathrm{~h}^{-1}$; Portwrinkle: $6.2 \mathrm{~g} \mathrm{~h}^{-1}$, Mount Batten: $1.8 \mathrm{~g} \mathrm{~h}^{-1}$; Jennycliff: $2.1 \mathrm{~g} \mathrm{~h}^{-1}$ ).

The tidal range during spring tides at these locations is $\sim 5 \mathrm{~m}$ ( 0.8 to $5.5 \mathrm{~m}$ relative to $\mathrm{CD})$, and comparisons were made between the upper shore (always covered by high water at neap tides), $\sim 4 \mathrm{~m}$ above $\mathrm{CD}$, and the lower shore (around the low-water mark at neap tides), $\sim 1 \mathrm{~m}$ above CD.

Sampling design. Differing tidal phases required different sampling techniques: traps at high water and direct counts on the shore at low water. These differing methodologies precluded formal statistical comparisons between data collected at low tide and those collected at high tide, but were used to give an indication

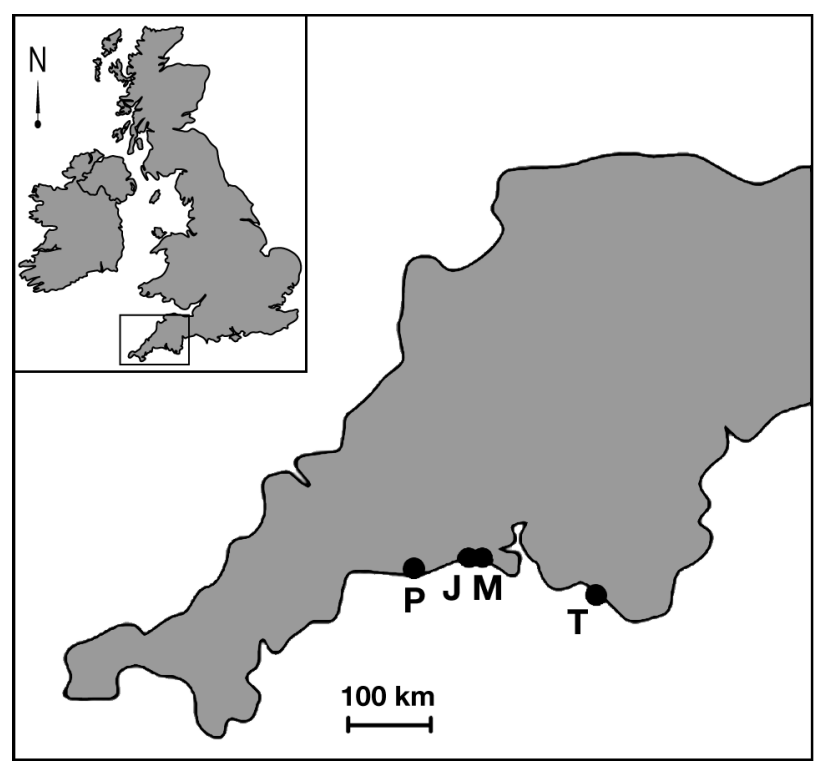

Fig. 1. Sampling sites in southwest Britain. Sheltered shores: $\mathrm{M}=$ Mount Batten; $\mathrm{J}=$ Jennycliff. Exposed shores: $\mathrm{P}=$ Portwrinkle; $\mathrm{T}=$ Thurlestone of differences in relative abundance of species and size classes between tidal phases. Sampling was undertaken during summer (June to September 2005), when crab activity is greatest (Naylor 1962, e.g. Choy 1986, Norman \& Jones 1992, Kaiser et al. 1993, Warman et al. 1993, Nickell \& Sayer 1998).

High-tide sampling: Sampling during immersion was via standard commercial creel crab traps $(60 \times 40 \times$ $35 \mathrm{~cm}$ [length $\times$ width $\times$ height], $1 \mathrm{~cm}$ mesh size). These were made of moulded heavy-duty plastic with two $8 \mathrm{~cm}$ diameter entrances and a bait tube (Coastal Fishing Supplies UK). Traps are a very efficient method to catch crabs (Miller 1990, Bell et al. 2003, Dunnington et al. 2005). During nocturnal high tides, 3 replicate traps were deployed on 2 separate occasions at each tidal level, shore and site permutation. Traps were fixed to the rock platform via anchoring points and were separated by at least $40 \mathrm{~m}$ within a $1000 \mathrm{~m}^{2}$ area of shore. This was considered sufficient to ensure independence of the area fished by each trap (see Miller 1990). All traps were baited with $2300 \mathrm{~g}$ fresh cut fish (Trachurus trachurus L., tested in preliminary trials) and were left for a single nocturnal high tide. Crabs were prevented from accessing the bait by placing the bait inside a fine-mesh ( 2 $\mathrm{mm})$ nylon bag which was then placed inside the in-built trap bait funnel. This procedure ensured that the bait could not influence crab stomach measurements such as fullness. The integrity of the bag was verified after each deployment and was invariably found to be $100 \%$. Comparisons between daytime and nocturnal high water were only made on 2 occasions on the lower shore. The main purpose of this sampling was to confirm results of previous studies that crabs were mainly active at night.

Since traps were likely to capture several species simultaneously, we examined the potential for nonindependence as a consequence of any inter- and intra-specific interactions. To examine whether immersion time had an effect on abundance patterns between tidal heights (differing duration of foraging window), a comparison of raw data as sampled and data adjusted for fishing (immersion) time per tidal height was also made. Callipers $(0.1 \mathrm{~mm})$ were used to record carapace width $(\mathrm{CW})$ and sex of all captured crabs. Based on classifications used in previous studies, juveniles of each species were defined as CW $\leq 35 \mathrm{~mm}$ for Carcinus maenas (Crothers 1967), $\leq 40 \mathrm{~mm}$ for Necora puber (Norman \& Jones 1993) and $\leq 40 \mathrm{~mm}$ for Cancer pagurus (Hall et al. 1993).

Low-tide sampling: Low-tide sampling during daylight compared the abundance and population structure of crabs between high and low tides. One-hour searches were made among boulders and crevices and on open rock on 2 sampling occasions on the upper and lower shore at each site at each location. To estab- 
lish the importance of nocturnal low-tide foraging, observations of tide-out crab activity were made at night at each location on 3 occasions. Preliminary observations indicated that the majority of predators that were active at this time foraged on the lower shore. Thus, for ease of sampling we restricted searches to the lower shore (1 $\mathrm{m}$ above $\mathrm{CD})$. Crabs that were observed to be active on the rock surface were collected by 2 observers working for $1 \mathrm{~h}$ each and commencing as the tide uncovered the lower shore. A hand-held torch with a red filter was used to detect crabs. This is known to minimise the disturbance on crab behaviour while maintaining the visibility range of the observer (Silva et al. 2004), and in the present study crabs did not attempt to escape when the observer pointed a direct light at them. All crabs were captured by hand, and only individuals outside their crevices or equivalent refuge in biotic substrata were sampled. For high-tide data, CW and sex were recorded for all crabs before release. Any predator-prey encounters that were observed were also recorded.

Stomach contents and prey availability. Stomachcontents analysis was restricted to crabs caught in traps during periods of immersion as this reflected prey eaten during the most recent foraging excursion and enabled diet to be compared with adjacent prey availability. On recovery of the traps, all captured animals were frozen at $-20^{\circ} \mathrm{C}$. All captured crabs were subsequently dissected and stomachs were removed. Since the presence of parasites or the moulting of crabs can hinder feeding behaviour (Williams 1982), gut contents were only examined for the intermoult stage of parasite-free predators. To assess the importance of intertidal prey in the diet of the crabs, hard body parts of limpets, barnacles and mussels were quantified. The points method (Williams 1981) was used to examine abundance since this method is suitable for prey that are ingested in large recognisable pieces or in their entirety. For limpets the number of radulae and pieces of shell (apex) were counted; for topshells the number of opercula or shell parts (apex); for chitons the number of radulae and anterior and posterior plates; for mussels the number of valves or umbos; and for barnacles the number of pairs of opercular plates.

To establish the relationship between stomach contents and prey availability (here interpreted as prey abundance), the relative abundance of prey species was recorded using 10 randomly positioned $50 \times 50 \mathrm{~cm}$ quadrats on both the upper and lower shore at each site at each location. For each quadrat, the number of individuals of mobile species and percentage cover of sessile invertebrates were recorded. Algae were not quantified.

Data analysis. Very few crabs were collected using traps during daytime high tide-Carcinus maenas: $\mathrm{n}=$
13; Necora puber: $\mathrm{n}=9$ and; Cancer pagurus: $\mathrm{n}=5$ ind.) and thus, only nocturnal high-tide data were used for subsequent analysis. These data were used to compare abundance and mean size of each species between shores of different exposure and between tidal heights using a 5-factor ANOVA. Factors were 'sampling occasion' (random with 2 levels: Date 1 and Date 2), 'shore level' (orthogonal, fixed with 2 levels: upper and lower), 'shore exposure' (orthogonal, fixed with 2 levels: sheltered and exposed), 'shore' (random, nested within exposure with 2 levels) and 'site' (random, nested within shore and exposure with 2 levels). As no significant differences in predator abundance were detected between sampling dates ( $p>0.3)$, data were subsequently pooled (Underwood 1997) and the analysis was performed on the remaining 4 factors. The abundance of crabs during nocturnal low tide was compared using the design described above but excluding the factor 'shore level', as only the lower shore was surveyed. Cochran's test was used to check homogeneity of variance, and appropriate transformations were made when this assumption was violated. Tests of homogeneity, ANOVA and post hoc StudentNewman-Keuls (SNK) tests were made using GMAV V5 for Windows (Institute of Marine Ecology, Sydney).

Possible biases in trap data as a result of predator interactions (e.g. aggression) were examined by testing for correlations between the numbers of Necora puber, the most aggressive of the species captured, versus the number of other species and also between relatively large and small individuals of each species. There were no correlations between the number of $N$. puber and the abundance of any other species (ANOSIM R $<0.1, \mathrm{p}>0.3$ ) or between large and small individuals of the same species (Carcinus maenas: ANOSIM R $<0.3, \mathrm{p}>0.1$; N. puber: ANOSIM R $<0.2$, $\mathrm{p}>0.3$; Cancer pagurus: ANOSIM R < 0.3, p > 0.1). Thus, traps were not compromised by problems of non-independence. Similar results were observed by Miller (1978), who found no effect of crab agonistic interactions.

The size-frequency distributions of predators at high tide were compared across the factors tidal elevation and exposure to wave action using a KolmogorovSmirnov test with a Scheirer-Ray-Hare extension in order to test for interactions between factors (Sokal \& Rohlf 1995). Spearman rank correlations were used to compare the relative abundance of prey in the stomach contents of predators with the relative abundance of prey on the shore. Multivariate analyses were used to examine the effect of shore exposure and tidal elevation on prey abundance and on predator diet (PRIMER 6 and PERMANOVA; Plymouth Marine Laboratory). PERMANOVA permutation tests were used to determine significant differences among factors. Bray- 
Curtis similarity coefficients were used to compare similarities between each pair of samples.

\section{RESULTS}

\section{Abundance and distribution of crabs at high tide}

There were no differences in abundance of crabs between shores of the same exposure or sites within shores in any of the analyses (Table 1). The main species captured in traps during nocturnal high tides were Carcinus maenas (418 ind.), Necora puber (216 ind.) and Cancer pagurus (131 ind.). The spider crab Maja squinado Herbst (19 ind.) was captured occasionally, but not in sufficient numbers to be included in analyses. A wide range of sizes were captured for all species, showing that traps were an effective method to study these species. CW and carapace length (CL) size ranges were: $M$. squinado: 98 to $136 \mathrm{~mm}(\mathrm{CW}), 125$ to $224 \mathrm{~mm}$ (CL); C. maenas: 10 to $73 \mathrm{~mm}(\mathrm{CW}), 4$ to 64 $\mathrm{mm}(\mathrm{CL}) ; N$. puber: 21 to $102 \mathrm{~mm}(\mathrm{CW}), 9$ to $82 \mathrm{~mm}$ (CL); and C. pagurus: 31 to $193 \mathrm{~mm}(\mathrm{CW}), 11$ to $144 \mathrm{~mm}$ (CL). Since crabs can enter the traps sideways, individuals at least up to $224 \mathrm{~mm}$ CL were captured.

Data were also standardised for hours of fishing per shore level, but as this gave similar patterns to the unstandardised data, the latter were used for interpretation and presentation of results. These direct comparisons of the number of crabs caught in traps on the upper and lower shore best represent the potential differences in predator distribution in relation to prey availability at a particular shore level. The abundance of crabs differed significantly between shore levels and according to exposure to wave action. With Carcinus maenas and Necora puber there were significant interactions between shore level and wave exposure
(Table 1): C. maenas was significantly more abundant on the upper shore at sheltered locations (Fig. 2), but abundance remained low on the lower shore at both sheltered and exposed locations, whereas $N$. puber was more abundant on the lower shore at sheltered locations and more abundant on sheltered than on exposed locations (Fig. 2). With Cancer pagurus there were significant differences between both shore level and wave exposure but without any interaction; there was greater abundance on the lower shore than on the upper shore, and at exposed rather than sheltered locations (Table 1, Fig. 2).

The size-frequency distribution of Carcinus maenas and Cancer pagurus varied significantly between tidal levels $(H=11.9$, df $=1, \mathrm{p}<0.001$ and $H=53.9$, df $=1$, $\mathrm{p}<0.001$, respectively) and with exposure $(H=12.6$, $\mathrm{df}=1, \mathrm{p}<0.001$ and $H=34.4$, df $=1, \mathrm{p}<0.001$, respectively). For both species median size was significantly larger on the lower shore than on the upper shore (Fig. 3). C. maenas was significantly larger at sheltered locations while $C$. pagurus was larger at exposed locations (Fig. 3). The size distribution of Necora puber did not differ significantly between tidal levels or with shore exposure $(H=5.7, \mathrm{df}=1, \mathrm{p}=$ not significant [ns] and $H=0.8, \mathrm{df}=1, \mathrm{p}=\mathrm{ns}$, respectively).

Consistently, more males than females were captured; of the 48 traps deployed, 36 contained more males than females (Carcinus maenas: $65 \%$ males, Necora puber: $71 \%$ males and Cancer pagurus: $73 \%$ males). Female C. maenas were more abundant on the upper shore, while males were more abundant on the lower shore. For C. pagurus, there were no apparent differences in the relative abundance of males and females between shore levels. For $N$. puber, there were no apparent differences in the relative abundance of females and males between shore levels or exposures.

Table 1. Carcinus maenas, Necora puber and Cancer pagurus. ANOVA comparing the abundance of 3 crab species between tidal levels and shores with differing exposure to wave action. Individuals were captured during high tide using traps. Significant effects are shown in bold and the directions of significant effects are illustrated in Fig. 2. TL: tidal level; Exp: exposure; Sh: shore; Si: site; RES: residual; $C$ : Cochran's test; ns: not significant

\begin{tabular}{|c|c|c|c|c|c|c|c|c|c|c|}
\hline \multirow[t]{2}{*}{ Source of variation } & \multirow[b]{2}{*}{ df } & \multicolumn{3}{|c|}{ C. maenas } & \multicolumn{3}{|c|}{ N. puber } & \multicolumn{3}{|c|}{ C. pagurus } \\
\hline & & MS & $F$ & $\mathrm{p}$ & MS & $F$ & $\mathrm{p}$ & MS & $F$ & $\mathrm{p}$ \\
\hline TL & 1 & 4524.08 & 596.74 & $<0.001$ & 93.52 & 897.80 & $<0.001$ & 147.00 & 60.83 & 0.01 \\
\hline Exp & 1 & 208.33 & 8.65 & 0.09 & 188.02 & 9.16 & 0.09 & 16.33 & 39.20 & 0.02 \\
\hline $\mathrm{Sh}(\operatorname{Exp})$ & 2 & 24.33 & 0.28 & 0.07 & 20.52 & 1.23 & 0.38 & 0.41 & 0.18 & 0.84 \\
\hline $\mathrm{Si}(\mathrm{Sh} \times \operatorname{Exp})$ & 4 & 86.04 & 1.05 & 0.39 & 16.65 & 3.67 & 0.06 & 2.29 & 1.10 & 0.37 \\
\hline $\mathrm{TL} \times \operatorname{Exp}$ & 1 & 70.08 & 24.74 & 0.03 & 2.52 & 24.20 & 0.03 & 1.33 & 0.55 & 0.53 \\
\hline $\mathrm{TL} \times \operatorname{Sh}(\operatorname{Exp})$ & 2 & 2.83 & 0.03 & 0.96 & 0.10 & 0.03 & 0.97 & 2.41 & 0.72 & 0.54 \\
\hline $\mathrm{TL} \times \mathrm{Si}(\mathrm{Sh} \times \operatorname{Exp})$ & 4 & 84.87 & 1.03 & 0.40 & 3.81 & 0.84 & 0.51 & 3.37 & 1.62 & 0.19 \\
\hline RES & 32 & 82.20 & & & 4.54 & & & 2.08 & & \\
\hline$C$ & & \multicolumn{3}{|c|}{0.32 (ns) } & \multicolumn{3}{|c|}{$0.26(\mathrm{~ns})$} & \multicolumn{3}{|c|}{$0.28(\mathrm{~ns})$} \\
\hline
\end{tabular}




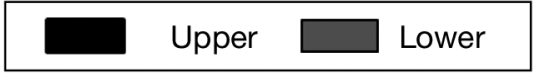

C. maenas
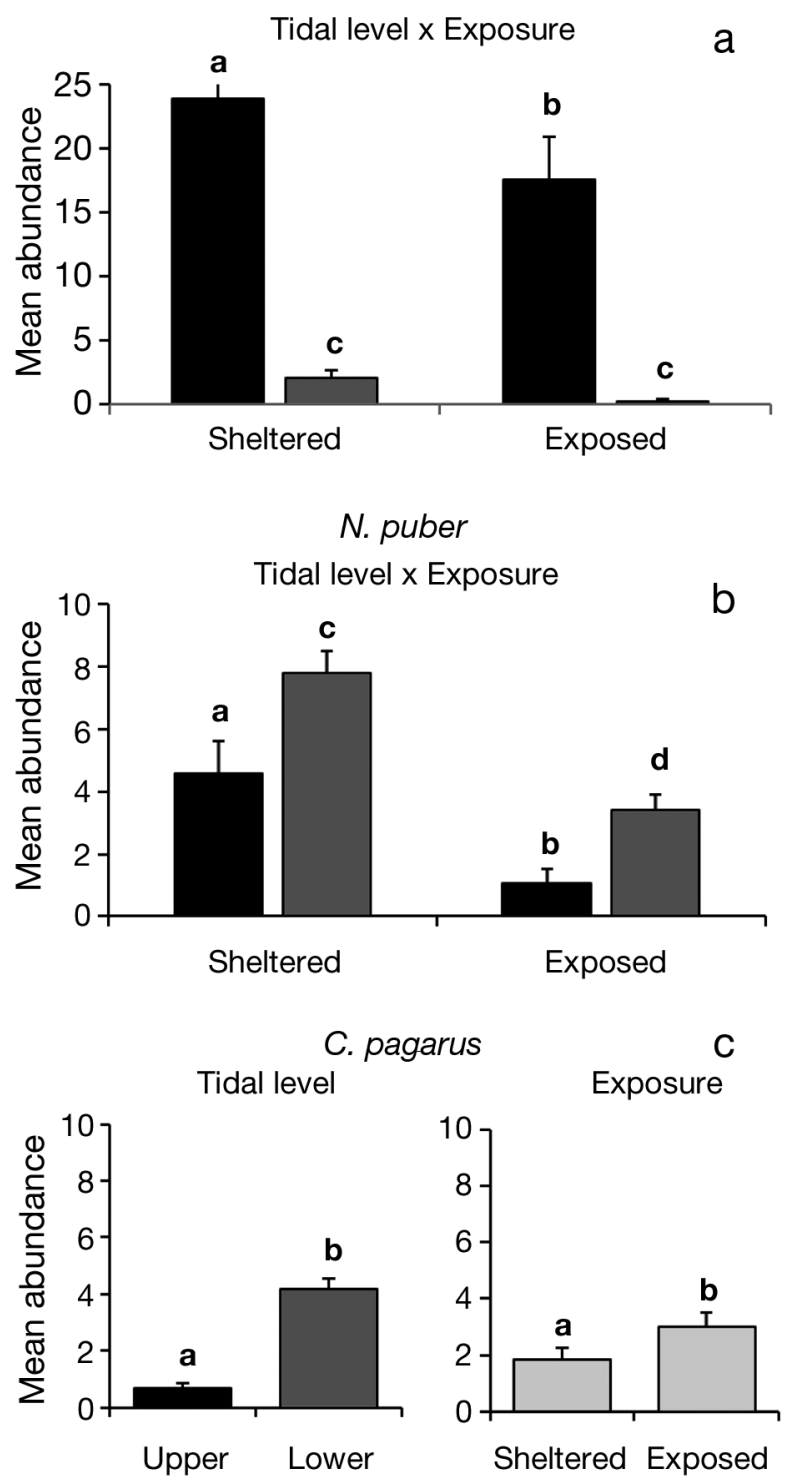

Fig. 2. (a) Carcinus maenas, (b) Necora puber and (c) Cancer pagurus. Mean number of individuals captured during nocturnal high tides between the upper and lower shore and between sheltered and exposed shores. Histograms show outcomes of Student-Newman-Keuls tests for significant effects (Table 1). Treatments with identical lower-case letters were not significantly different. Error bars represent SE

\section{Abundance and distribution of crabs at low tide}

For data collected at low tide, there were no differences in abundance between shores or sites within shores for all species (Table 2a). Carcinus maenas were significantly more abundant on the upper shore at sheltered locations, while Necora puber and Cancer pagu- rus were most abundant on the lower shore at both exposed and sheltered locations (Table 2a). C. maenas were larger (mean difference in size: $\sim 12 \%$ ) on the upper shore than on the lower shore at exposed locations (Table $2 b$ ). The opposite pattern was apparent on sheltered locations, with larger individuals (mean difference in size: $\sim 10 \%$ ) on the lower shore than on the upper shore. $N$. puber and C. pagurus were significantly larger on the upper shore than on the lower shore at both sheltered and exposed locations (Table $2 \mathrm{~b}$ ). There were no apparent differences in the relative abundance of females and males collected at low tide. This effect was consistent between all species, locations of different exposure and between shore levels.

The only species that was active during nocturnal low tides was Carcinus maenas, with an average of $132 \pm 5(\mathrm{SE})$ individuals recorded active per observer per hour. During these periods individuals were significantly more abundant in sheltered locations $\left(\mathrm{df}_{1,16}\right.$, $F=91.81, \mathrm{p}=0.01$ ). This pattern of abundance mirrored that during daytime low tides. There were no differences in the abundance of $C$. maenas at smaller spatial scales between shores or sites within shores. On average, however, 15 predator-prey encounters were recorded per hour of observation. The majority of these individuals were feeding on patellid limpets (average limpet size: $15.0 \pm 2.3 \mathrm{~mm}$ ).

For all crab species, the modal size of individuals captured at low tide was markedly smaller than that of individuals captured at high tide (Fig. 3), suggesting that larger predators were moving into the intertidal zone during high tide, presumably to forage.

\section{Stomach contents}

The stomachs of 750 crabs were examined, and the majority of these were $30 \%$ or more full. The chiton Lepidochitona cinerea (L.), limpets Patella spp. (not possible to identify to species level), the barnacle Elminius modestus Darwin, the mussel Mytilus spp. (not possible to identify to species level) and the brown algae Laminaria spp. (not a hard-bodied prey part but easily recognisable) were the most common prey items; these items accounted for $>50 \%$ of the predator stomach contents (Table 3). Typical examples of hard body parts recovered from predator stomachs are shown in Fig. 4. Of all the prey items with hard-bodied parts, limpets Patella spp. and chitons L. cinerea were the most abundant items in the stomachs of these predators, particularly of Carcinus maenas and Cancer pagurus (Table 3 ). The permutational analysis showed that prey composition in the stomach contents of all predator species did not vary significantly with sex or age (juvenile and adult). 

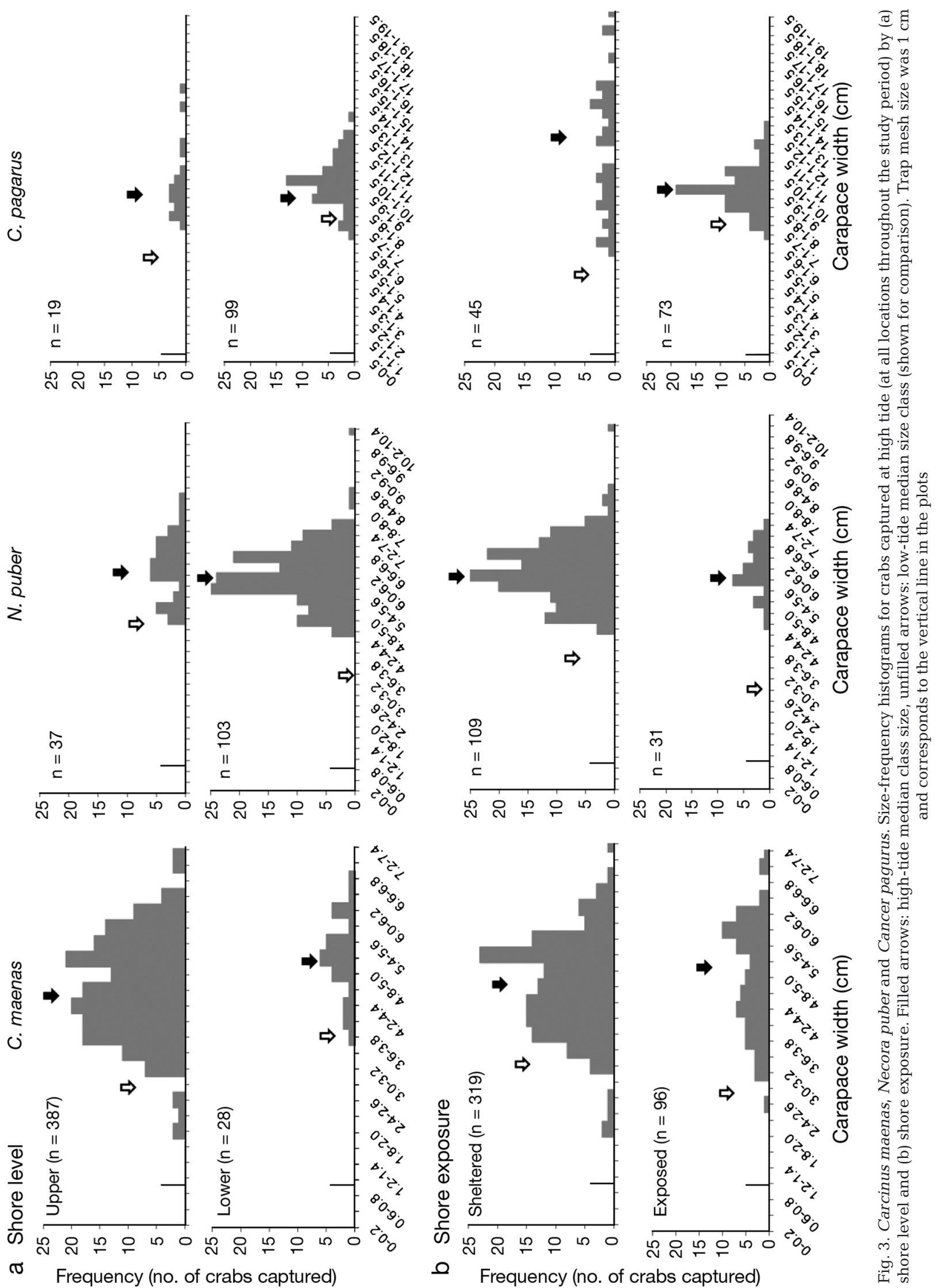

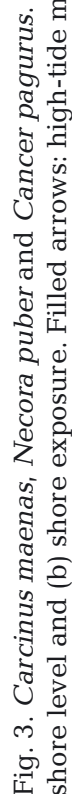

Frequency (no. of crabs captured) 
Table 2. Carcinus maenas, Necora puber and Cancer pagurus. ANOVA comparing (a) abundance and (b) size of crabs present in the intertidal during daytime low tide between tidal levels and shores of different exposures. Significant effects are shown in bold: ${ }^{*}<<$ $0.05 ;{ }^{* *} p<0.01$. TL: tidal level; Exp: exposure; Sh: shore; Si: site; RES: residual; $C$ : Cochran's test; SNK: Student-Newman-Keuls; Sqrt: square root; ns: not significant

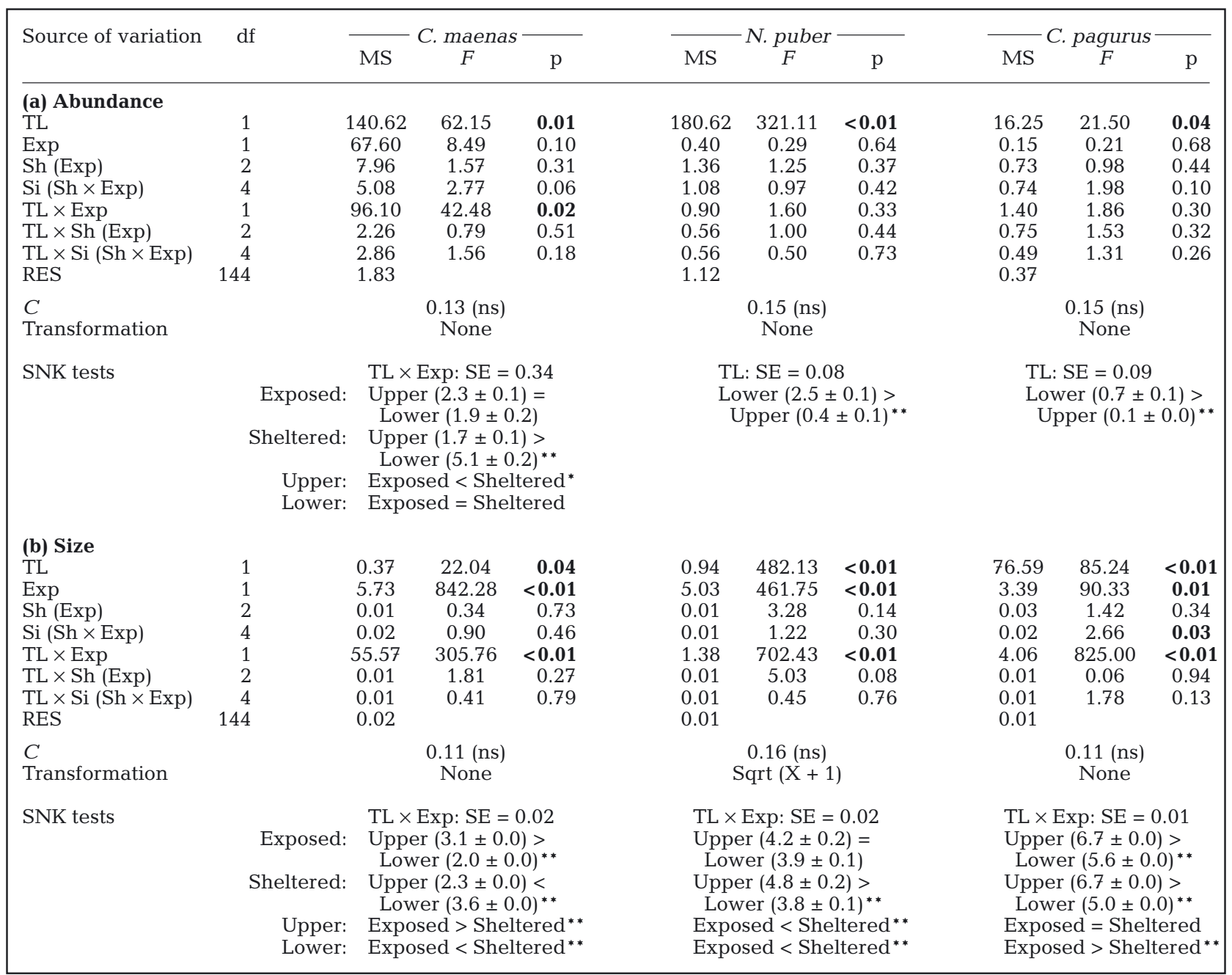

\section{Distribution patterns of intertidal prey species}

Permutational analysis of prey abundance showed major differences in assemblages between shore levels (pseudo- $F_{1,144}=3.90$, permutational $\mathrm{p}=0.03$ ). SIMPER analysis showed that the species which contributed the most to these differences were Patella spp (28.6\%), Chthamalus spp. (16.0\%), Gibbulla umbilicalis Da Costa $(11.1 \%)$ and Osillinus lineata Da Costa (10.4\%) No differences in prey assemblages were detected between: sheltered and exposed shores (pseudo- $F_{1,144}=8.17$, permutational $\mathrm{p}=0.07$ ), shores with different exposure (pseudo- $F_{2,144}=1.93$, permutational $\mathrm{p}=0.15$ ), sites within shores (pseudo- $F_{4,144}=9.11$, permutational $\mathrm{p}=$ 0.08), or for any interactions among these factors. No correspondence between stomach contents and patterns of prey abundance was evident for any of the crab species (Spearman correlation tests: for all crab species and factors, correlation coefficient was $<0.3$, $\mathrm{df}=9, \mathrm{p}<0.01)$.

\section{DISCUSSION}

Traps proved to be an efficient method with which to sample crabs that were active during high tide. Three species were easily sampled with this method, yielding a total of 765 crabs with a wide range of sizes up to $193 \mathrm{~mm}$ CW in 48 trap deployments. There was no evidence of intra- or inter-specific agonistic interactions leading to non-independence or other biases in the trap data. Few crabs were caught during daytime high tides, confirming previous observations (e.g. Dare \& Edwards 1981). 
Table 3. Carcinus maenas, Necora puber and Cancer pagurus. Relative abundance $(\%)$ of prey items found in the quadrats on the shore and in crabs' stomachs. Data are pooled for all shore heights and exposure to wave action. nq: not quantified

\begin{tabular}{|c|c|c|c|c|}
\hline Prey species & $\begin{array}{l}\text { \% of prey species } \\
\text { naturally on the shore } \\
\text { (rank abundance) }\end{array}$ & \multicolumn{3}{|c|}{$\begin{array}{l}\% \text { of prey found in predator } \\
\text { stomachs (rank abundance) }\end{array}$} \\
\hline \multicolumn{5}{|l|}{ Barnacles } \\
\hline Chthamalus stellatus & $\mathrm{nq}$ & $1.1(6)$ & 0 & $3.6(4)$ \\
\hline Chthamalus montagui & $39.9(2)$ & 0 & $6.5(8)$ & $7.1(3)$ \\
\hline Elminius modestus & $\mathrm{nq}$ & $4(5)$ & $7.1(7)$ & $28.6(2)$ \\
\hline \multicolumn{5}{|l|}{ Gastropods } \\
\hline Patella spp. & $46.4(1)$ & $33.9(2)$ & $8.2(6)$ & $39.3(1)$ \\
\hline Littorina littorea & $1.4(6)$ & 0 & $10.6(3)$ & $3.6(5)$ \\
\hline Gibbula umbilicalis & $5.4(3)$ & $10.2(4)$ & $8.8(5)$ & 0 \\
\hline Osilinus lineatus & $2.3(4)$ & 0 & 0 & 0 \\
\hline Nucella lapillus & $0.3(8)$ & 0 & 0 & 0 \\
\hline \multicolumn{5}{|l|}{ Polyplacophors } \\
\hline Lepidochitona cinereus & $1.7(5)$ & $40.1(1)$ & $12.9(2)$ & $7.1(3)$ \\
\hline \multicolumn{5}{|l|}{ Bivalves } \\
\hline Mytilus edulis & $0.6(7)$ & $10.7(3)$ & $29.4(1)$ & 0 \\
\hline \multicolumn{5}{|l|}{ Algae } \\
\hline Laminaria spp. & nq & 0 & $10(4)$ & 0 \\
\hline
\end{tabular}

\section{Spatial patterns in the abundance of crabs}

The present study showed that 3 species of crabs forage in substantial numbers in the intertidal zone during high tide and that their abundance is significantly influenced by exposure to wave action: Necora puber and Carcinus maenas were more abundant at sheltered locations while Cancer pagurus was more abundant on exposed shores. These distribution patterns were consistent across sampling dates and sites; thus, the effect of exposure to wave action is likely to be general. This pattern of distribution has not previously been described for these species, but some similar results are available for spiny lobsters Panulirus interruptus on the west Pacific coast (see Robles 1987, Robles et al. 2001). Our findings are
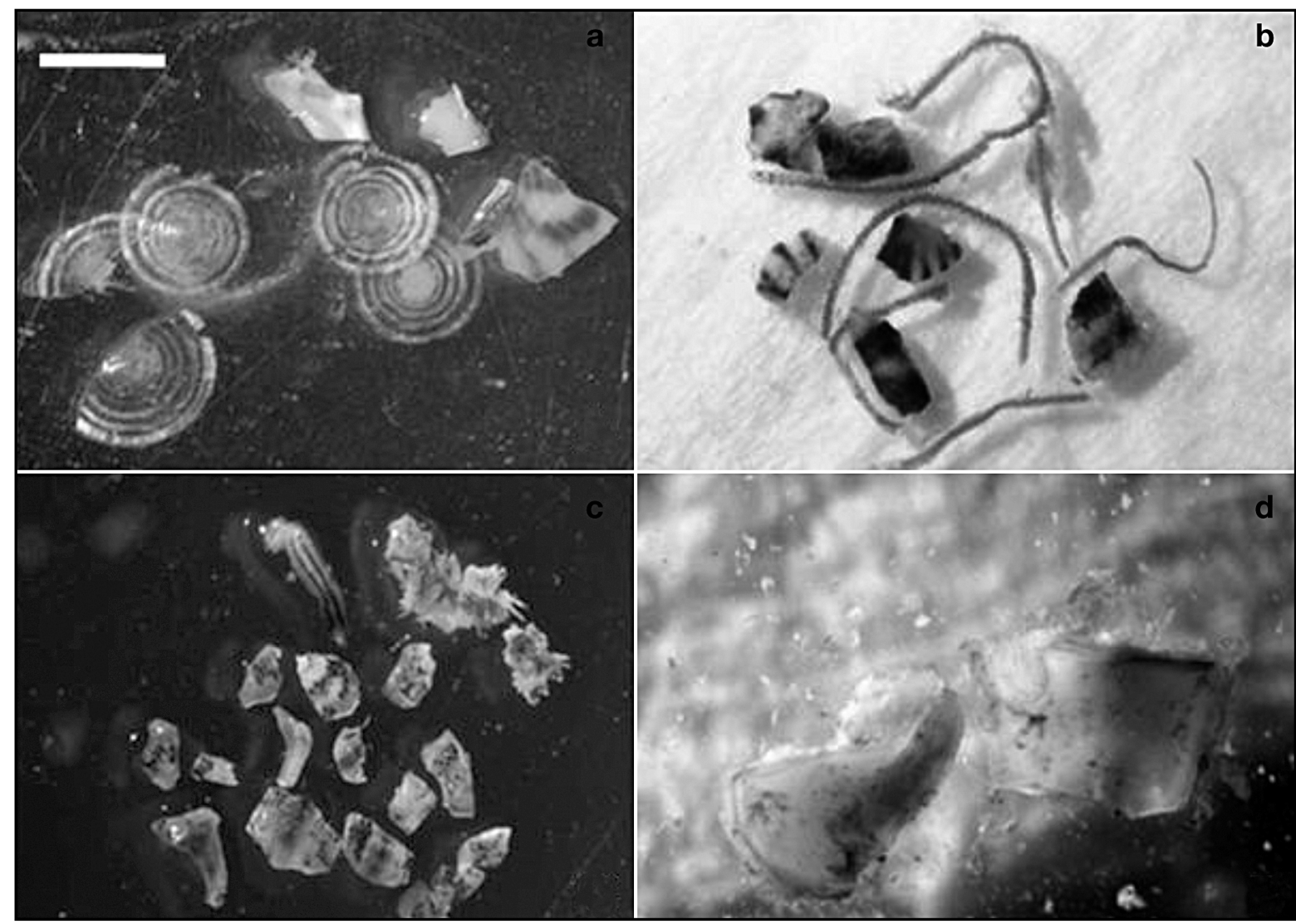

Fig 4. Carcinus maenas, Necora puber and Cancer pagurus. Examples of prey items removed from crabs' stomachs: (a) operculum of Gibbula umbilicalis, (b) shell remains and radula of Patella spp., (c) plates and radula of Lepidochitona cinerea, (d) plates of barnacles. Scale bar $=50 \mathrm{~mm}(\mathrm{a}-\mathrm{c}), 10 \mathrm{~mm}(\mathrm{~d})$ 
similar to those of Pallas et al. (2006), who concluded that wave exposure had a significant species-specific effect on the distribution of brachyurans in shallow waters of the Ria de La Corunã (northwest Spain).

The present findings also indicate that prey availability may not be the major factor influencing the variation in crab abundance across the wave-exposure gradient, as there was no relationship between stomach contents and prey availability along this gradient. According to the model of community regulation proposed by Menge \& Sutherland (1987), the effect of predation by mobile consumers is low in stressful conditions because their activity is minimal and/or their feeding ability is compromised (see Menge 1978a). Here, we present evidence which indirectly supports the model of Menge \& Sutherland (1987), whereby 2 species of crab, Carcinus maenas and Necora puber, were most abundant at sheltered locations. This pattern was not found for Cancer pagurus, which was more abundant at exposed locations; however, its abundance was considerably lower than that of the other 2 species. It is possible that the relatively greater robustness of this species allows it to exploit habitats not occupied by $C$. maenas and $N$. puber. Based on abundance patterns, the potential impact of crabs on prey populations appears to be influenced at large spatial scales by exposure to wave action, indicating that greater predation pressure may be exerted at sheltered locations, where crabs were more abundant. This interpretation is in agreement with the Menge \& Sutherland (1987) environmental stress model, where consumer effect is inversely related to environmental stress. Crab abundance and predation effects have been correlated in previous studies, whereby prey with stronger shells were present at sites where crabs were more abundant (Vermeij 1976, Hughes \& Seed 1981, Yamada \& Boulding 1998). Crabs exert significant control on the abundance of limpets on moderately sheltered shores in southwest Britain (Silva et al. 2008). Limpets are known to have a key influence on intertidal assemblages (Hawkins \& Hartnoll 1983, Jenkins et al. 2005, Coleman et al. 2006), and also to be less abundant at sheltered than at exposed locations (Hawkins \& Hartnoll 1983, Jenkins et al. 1999). Dense algae cover increases siltation at sheltered locations, which is known to be detrimental for limpets (Hawkins et al. 1992, Raffaelli \& Hawkins 1996). The present study further indicates that predation by crabs may act together with algal cover and siltation to reduce the abundance of limpets.

The abundance of crabs differed between shore levels, with greater abundance on the lower shore (except for Carcinus maenas); however, the causes of these patterns are not clear. Habitat and prey availability (Robles et al. 1990, Holsman et al. 2006) and competition and predation (Almany 2004) have all been suggested as important factors influencing the distribution of these animals, and it is probable that differences in crab distribution among shore levels are a combined result of prey distribution and time spent on foraging. Necora puber and Cancer pagurus are potentially attracted to prey that are restricted to the lower shore, such as chitons and some (smaller) limpets, and because they also have more feeding time at this shore level. It is also possible that $N$. puber and C. pagurus have to travel further into the intertidal zone than C. maenas, as they are likely to take refuge in the sublittoral zone when the tide is out due to their tendency to be sublittoral species, and this influences their distribution on the shore. C. maenas is less robust than the other 2 species but is very agile; it therefore seems possible that it moves higher on the shore to avoid inter-specific competition and also to access different prey such as barnacles and dogwhelks. The diet of $C$. maenas is known to be based mainly on a wide variety of intertidal prey (see Hughes \& Elner 1979, Elner 1981, Mascaró \& Seed 2001). A similar behavioural trend to move up the shore according to prey availability has been reported for other inshore crustacean migrants such as spiny lobsters Palinurus interruptus Randall, 1840, whereby lobsters fed selectively on lower-shore mussels (Robles et al. 1990). Other Cancer spp. (Cancer magister Dana, 1852) have also been found to undertake inshore migrations during high tide in estuaries (Holsman et al. 2006). In these cases, crab distribution in the intertidal zone was dependent on the type of habitat, with a reported preference for mud and sand flats, where the abundance of their main prey, sand shrimp Crangon spp., was also higher (see Stevens et al. 1982, Holsman et al. 2006).

Based on the stomach contents, which mainly included intertidal prey, and also taking into consideration the relatively high levels of crab abundance, it is likely that greater abundance of crabs on the lower shore may result in a vertical predation gradient, with greater pressure on the lower shore and subsequent consequences for prey distribution. Mortality in limpet populations due to crab predation has previously been shown at the lower shore at Mount Batten (Silva et al. 2008), a shore used in the present study, and in this region, crabs have been shown to attack limpets frequently (Thompson et al. 2000). This may also influence intra-specific competition for space or food resources among these grazers (Boaventura et al. 2002).

For all 3 crab species, males were more abundant than females, and this pattern was consistent between shores (see Hunter \& Naylor 1993, Warman et al. 1993 for similar findings). It is not clear why males seem to be more active than females; however, some authors have suggested that male crabs exhibit the most persistent endogenous circatidal rhythms of locomotor 
activity (Naylor 1958, Atkinson \& Parsons 1973, Hunter \& Naylor 1993), and it is also possible that because males tend to be larger than females, their locomotory activity encompasses more extensive areas of the shore (Hunter \& Naylor 1993).

In the present study, crabs had a generalist diet, which included a number of dominant prey, but patterns in the diet composition were not related to the distribution of prey on the shore. Previous studies have reported that the diet of crabs can be driven by prey availability (Paul 1981, Wear \& Haddon 1987, Edgar 1990), while other studies indicate that accessibility of prey (capacity to find, capture and ingest the prey), habitat (refuges) or preference for prey types or sizes are the main drivers of spatial foraging patterns (e.g. Cannicci et al. 2002, León \& Stotz 2004, Pallas et al. 2006). It was of interest that chitons Lepidochitona cinereus composed up to $40 \%$ of the diet of the crabs sampled in the present study $(40 \%$ for Carcinus maenas, $13 \%$ for Necora puber and $7 \%$ for Cancer pagurus), suggesting that chitons are important intertidal prey. On these shores chitons are cryptic grazers that live on the underside of stones and in crevices and are mainly active during nocturnal high tide, when they feed on rock surfaces (Evans 1951). This pattern of activity coincides with the period of greatest crab activity as reported in the present study. It would be particularly interesting to gather more information on the dynamics of crab-chiton interactions, since this is the first account showing the importance of these grazers in the diet of crabs in the intertidal zone.

Substantial numbers of Carcinus maenas were active during nocturnal low tides. Foraging at low tide has previously been reported for other species such as Pachygrapsus marmoratus (e.g. Cannicci et al. 1999, Flores \& Paula 2001, Silva et al. 2004) but had not been quantified for C. maenas. Tide-out foraging at night is likely to reduce desiccation stress and reduce the risk of predation on the crabs by fish and birds (e.g. Ahsanullah \& Newell 1977, Ellis et al. 2005). C. maenas that were observed at low tide at night were feeding on limpets, and stomachcontent analysis of individuals captured at high tide indicated that limpets composed $\sim 40 \%$ of the C. maenas diet. Hence, limpets would appear to be subject to considerable predation by crabs at night during both lowand high-water periods (see also Silva et al. 2008).

\section{Migration of crabs into the intertidal zone during high tide}

The present data support the hypothesis that there is a strong trophic linkage between subtidal predators and intertidal prey: individuals captured at high water were larger than individuals captured after extensive searches at low water, indicating a migration of crabs into the intertidal zone during high water. This pattern has also been reported for Carcinus maenas in the Menai Strait (UK) (e.g. Hunter \& Naylor 1993, Warman et al. 1993) using similar methods to those used in the present study, but migration into the intertidal zone has not previously been shown for Necora puber or Cancer pagurus, which are both abundant and commercially important species. Differences in the abundance of crabs between high water and low water have important contextual implications for studies investigating the ecology of these mobile predators and predator-prey interactions in shallow-water habitats, since low-tide observations of crab populations and their behaviour are likely to be unrepresentative of the total (low and high tide) effect of crab predation. Large individuals such as some of the crabs studied here can cover substantial areas of the shore at high water and can hence access a variety of species. Traditionally, subtidal and intertidal habitats have been considered to be essentially separate habitats, but the present study suggests that crabs act as an important trophic linkage. Juvenile crabs including Carcinus maenas are known to use the intertidal as a nursery, moving into deeper waters as they grow (Eriksson \& Edlund 1977 , Pihl \& Rosenberg 1982). The present study shows that larger individuals use the intertidal zone during high water to feed. We therefore consider that to fully understand the role of these predators in shaping intertidal assemblages, it is necessary to take into account differences in foraging activities between tidal phases, tidal heights and locations with differing exposure to wave action. The present work demonstrates that an additional trophic level of highly mobile predators must be built into conceptual frameworks of connectivity between the sublittoral and litoral habitats, as suggested by recent studies (see Rilov \& Schiel 2006a,b, Jones \& Shulman 2008, Silva et al. 2008). More research is therefore required to verify the extent of top-down control by crabs, especially on grazers (e.g. Thompson et al. 2004) in the intertidal zone. Such work should focus on replicated manipulative experiments to establish the importance of predator-prey interactions at a range of spatial scales.

Acknowledgements. We thank P. Rendle (Marine Biological Association of the United Kingdom) for sharing his knowledge on the use of commercial pots, and M. Browne, R. Ticehurst and L. Firth for help with data collection. This work and A.C.F.S. were funded by the 'Fundação para a Ciência e Tecnologia', Portugal (PhD grant SFRH/BD/19077/2004). S.J.H. was funded by a Natural Environment Research Council (NERC) Grant In Aid to the Marine Biological Association of the United Kingdom. This paper also contributes to Theme 4 of Oceans 2025, the NERC strategic science programme. These experiments comply with the laws of the UK. 


\section{LITERATURE CITED}

Ahsanullah RM, Newell RC (1977) The effects of humidity and temperature on water loss in Carcinus maenas (L.) and Portunus marmoreus (Leach). Comp Biochem Physiol A 56:593-599

Almany GR (2004) Differential effects of habitat complexity, predators and competitors on abundance of juvenile and adult coral reef fishes. Oecologia 141:105-113

Atkinson RJA, Parsons AJS (1973) Seasonal patterns of migration and locomotor rhythmicity in populations of Carcinus. J Sea Res 7:81-93

Bell MC, Eaton DR, Bannister RCA, Addison JT (2003) A mark-recapture approach to estimating population density from continuous trapping data: application to edible crabs, Cancer pagurus, on the east coast of England. Fish Res 65:361-378

Bernardez C, Freire J, Gonzalez-Gurriaran E (2000) Feeding of the spider crab Maja squinado in rocky subtidal areas of the Ria de Arousa (north-west Spain). J Mar Biol Assoc UK 80:95-102

Bishop MJ, Wear SL (2005) Ecological consequences of ontogenetic shifts in predator diet: seasonal constraint of a behaviourally mediated indirect interaction. J Exp Mar Biol Ecol 326:199-206

Boaventura D, Cancela da Fonseca L, Hawkins S (2002) Analysis of competitive interactions between the limpets Patella depressa Pennant and Patella vulgata L. on the northern coast of Portugal. J Exp Mar Biol Ecol 271: 171-188

Boulding EG, Holst M, Pilon V (1999) Changes in selection on gastropod shell size and thickness with wave-exposure on Northeastern Pacific shores. J Exp Mar Biol Ecol 232: 217-239

Brousseau DJ, Fillipowicz A, Baglivo JA (2001) Laboratory investigations of the effects of predator sex and size on prey selection by the Asian crab, Hemigrapsus sanguineus. J Exp Mar Biol Ecol 262:199-210

Burrows MT, Kawai K, Hughes RN (1999) Foraging by mobile predators on a rocky shore: underwater TV observations of movements of blennies Lipophrys pholis and crabs Carcinus maenas. Mar Ecol Prog Ser 187:237-250

- Cannicci S, Paula J, Vannini M (1999) Activity pattern and spatial strategy in Pachygrapsus marmoratus (Decapoda: Grapsidade) from Mediterranean and Atlantic shores. Mar Biol 133:429-435

> Cannicci S, Gomei M, Boddi B, Vannini M (2002) Feeding habits and natural diet of the intertidal crab Pachygrapsus marmoratus: Opportunistic browser or selective feeder? Estuar Coast Shelf Sci 54:983-1001

Choy SC (1986) Natural diet and feeding habits of the crabs Liocarcinus puber and L. holsatus (Decapoda, Brachyura, Portunidae). Mar Ecol Prog Ser 31:87-99

Coleman RA, Underwood AJ, Benedetti-Cecchi L, Aberg P and others (2006) A continental scale evaluation of the role of limpet grazing on rocky shores. Oecologia 147:556-564

Crothers JH (1967) The biology of the shore crab Carcinus maenas (L.). I. The background: anatomy, growth and life history. Field Stud 2:407-434

Dare PJ, Edwards DB (1981) Underwater television observations on the intertidal movements of shore crabs, Carcinus maenas, across a mudflat. J Mar Biol Assoc UK 61:107-116

Dunnington MJ, Wahle RA, Bell MC, Geraldi NR (2005) Evaluating local population dynamics of the American lobster, Homarus americanus, with trap-based mark-recapture methods and seabed mapping. N Z J Mar Freshw Res 39: 1253-1276
Edgar GJ (1990) Predator-prey interactions in seagrass beds II. Distribution and diet of the blue manna crab Portunus pelagicus Linnaeus at Cliff Head, Western Australia. J Exp Mar Biol Ecol 139:23-32

Ellis JC, Chen W, O'Keefe B, Shulman MJ, Witman JD (2005) Predation by gulls on crabs in rocky intertidal and shallow subtidal zones of the Gulf of Maine. J Exp Mar Biol Ecol 324:31-43

Elner RW (1981) Diet of green crab Carcinus maenas (L.) from Port Herbert, southwestern Nova Scotia. J Shellfish Res 1:89-94

Eriksson S, Edlund AM (1977) On the ecological energetics of 0-group Carcinus maenas from shallow sandy bottom in Gullmar fjord, Sweden. J Exp Mar Biol Ecol 30:233-248

Evans F (1951) An analysis of the behaviour of Lepidochitona cinereus in response to certain physical features of the environment. J Anim Ecol 20:1-10

Faria C, Almada VC (2006) Patterns of spatial distribution and behaviour of fish on a rocky intertidal platform at high tide. Mar Ecol Prog Ser 316:155-164

- Flores A, Paula J (2001) Intertidal distribution and species composition of brachyuran crabs at two rocky shores in central Portugal. Hydrobiologia 449:171-177

Freire J (1996) Feeding ecology of Liocarcinus depurator (Decapoda:Portunidae) in the Ría de Arousa (Galicia, north-west Spain): effects of habitat, season and life history. PSZN I: Mar Ecol 126:297-311

Hall S, Robertson M, Basford D, Fryer R (1993) Pit-digging by the crab Cancer pagurus: a test for long-term, large-scale effects on infaunal community structure. J Anim Ecol 62: $59-66$

Hawkins SJ, Hartnoll R (1983) Grazing of intertidal algae by marine invertebrates. Oceanogr Mar Biol Annu Rev 21: 195-282

Hawkins SJ, Hartnoll RG, Kain JM, Norton TA (1992) Plantanimal interactions in the marine benthos. In: John DM, Hawkins SJ, Price JH (eds) Plant-animal interactions on hard substrata in the north-east Atlantic, Vol 46. Clarendon Press, Oxford, p 1-32

Hollingsworth A, Connolly RM (2006) Feeding by fish visiting inundated subtropical saltmarsh. J Exp Mar Biol Ecol 336: 88-98

> Holsman KK, McDonald PS, Armstrong DA (2006) Intertidal migration and habitat use by subadult Dungeness crab Cancer magister in a NE Pacific estuary. Mar Ecol Prog Ser 308:183-195

Hughes RN (1980) Predation and community structure. In: Price JH, Irvine DEG, Farnham WF (eds) The shore environment, Vol 2: Ecosystems. Academic Press, London, p 699-728

Hughes RN, Elner RW (1979) Tactics of a predator, Carcinus maenas, and morphological responses of the prey Nucella lapillus. J Anim Ecol 48:6-78

$>$ Hughes RN, Seed R (1981) Size selection of mussels by the blue crab Callinectes sapidus: Energy maximizer or time minimizer? Mar Ecol Prog Ser 6:83-89

> Hughes RN, Seed R (1995) Behavioural mechanisms of prey selection in crabs. J Exp Mar Biol Ecol 193:225-238

> Hunter E, Naylor E (1993) Intertidal migration by the shore crab Carcinus maenas. Mar Ecol Prog Ser 101:131-138

> Jenkins SR, Hawkins SJ, Norton TA (1999) Direct and indirect effects of a macroalgal canopy and limpet grazing in structuring a sheltered inter-tidal community. Mar Ecol Prog Ser 188:81-92

Jenkins SR, Coleman RA, Della Santina P, Hawkins SJ, Burrows MT, Hartnoll RG (2005) Regional scale differences in the determinism of grazing effects in the rocky intertidal. 
Mar Ecol Prog Ser 287:77-86

Jones PL, Shulman MJ (2008) Subtidal-intertidal trophic links: American lobsters [Homarus americanus (MilneEdwards)] forage in the intertidal zone on nocturnal high tides. J Exp Mar Biol Ecol 361:98-103

> Jonsson PR, Granhag L, Moschella PS, Aberg P, Hawkins SJ, Thompson RC (2006) Interactions between wave action and grazing control the distribution of intertidal macroalgae. Ecology 87:1169-1178

Kaiser MJ, Hughes RN, Reid DG (1990) Chelal morphometry, prey-size selection and aggressive competition in green and red forms of Carcinus maenas (L). J Exp Mar Biol Ecol 140:121-134

Kaiser MJ, Hughes RN, Gibson RN (1993) Factors affecting diet selection in the shore crab, Carcinus maenas (L.). Anim Behav 45:83-92

Karlsson K, Christiansen ME (1996) Occurrence and population composition of the edible crab (Cancer pagurus) on rocky shores of an islet on the south coast of Norway. Sarsia 81:307-314

> Lee JT, Ross C, Malcolm J (2006) Population dynamics and growth of juveniles of the velvet swimming crab Necora puber (Decapoda: Portunidae). Mar Biol 148:609-619

León RI, Stotz WB (2004) Diet and prey selection dynamics of Cancer polyodon in three different habitat types in Tongoy Bay, Chile. J Mar Biol Assoc UK 84:751-756

Lewis JR (1964) The ecology of rocky shores. English University Press, London

> Lohrer AM, Fukui Y, Wada K, Whitlatch RB (2000) Structural complexity and vertical zonation of intertidal crabs, with focus on habitat requirements of the invasive Asian shore crab, Hemigrapsus sanguineus (de Haan). J Exp Mar Biol Ecol 244:203-217

Mascaró M, Seed R (2001) Foraging behaviour of juvenile Carcinus maenas (L.) and Cancer pagurus L. Mar Biol 139: 1135-1145

Menge BA (1978a) Predation intensity in a rocky intertidal community: effect of an algal canopy, wave action and desiccation on predator feeding rates. Oecologia 34:17-35

Menge BA (1978b) Predation intensity in a rocky intertidal community: relation between predator foraging activity and environmental harshness. Oecologia 34:1-16

Menge BA (2000) Top-down and bottom-up community regulation in marine rocky intertidal habitats. J Exp Mar Biol Ecol 250:257-289

> Menge B, Sutherland J (1976) Species diversity gradients: synthesis of the roles of predation, competition, and temporal heterogeneity. Am Nat 110:351-369

Menge BA, Sutherland JP (1987) Community regulation: variation in disturbance, competition, and predation in relation to environmental stress and recruitment. Am Nat 130: $730-757$

Menge BA, Daley BA, Lubchenco J, Sanford E and others (1999) Top-down and bottom-up regulation of New Zealand rocky intertidal communities. Ecol Monogr 69: 297-330

> Menge BA, Sanford E, Daley BA, Freidenburg TL, Hudson G, Lubchenco J (2002) Inter-hemispheric comparison of bottom-up effects on community structure: insights revealed using the comparative-experimental approach. Ecol Res 17:1-16

Menge BA, Lubchenco J, Bracken MES, Chan F and others (2003) Coastal oceanography sets the pace of rocky intertidal community dynamics. Proc Natl Acad Sci USA 100: 12229-12234

Miller RJ (1978) Entry of Cancer productus to baited traps. J Cons Int Explor Mer 38:220-225
Miller RJ (1990) Effectiveness of crabs and lobster traps. Can J Fish Aquat Sci 47:1228-1251

Moksnes PO (2002) The relative importance of habitatspecific settlement, predation and juvenile dispersal for distribution and abundance of young juvenile shore crabs Carcinus maenas L. J Exp Mar Biol Ecol 271:41-73

Moksnes PO (2004) Interference competition for space in nursery habitats: density-dependent effects on growth and dispersal in juvenile shore crabs Carcinus maenas. Mar Ecol Prog Ser 281:181-191

Naylor E (1958) Tidal and diurnal rhythms of locomotory activity in Carcinus maenas (L.). J Exp Biol 35:602-610

> Naylor E (1962) Seasonal changes in a population of Carcinus maenas (L.) in the littoral zone. J Anim Ecol 31: 601-609

Newell RC, Ahsanull M, Pye VI (1972) Aerial and aquatic respiration in shore crab Carcinus maenas (L). Comp Biochem Physiol A 43:239-252

Nickell LA, Sayer MDJ (1998) Occurrence and activity of mobile macrofauna on a sublittoral reef: diel and seasonal variation. J Mar Biol Assoc UK 78:1061-1082

Norman CP, Jones MB (1990) Utilisation of brown algae in the diet of the velvet swimming crab Liocarcinus puber (Brachyura: Portunidae). Trophic relationships in the marine environment. Proc 24th Eur Mar Biol Symp. Aberdeen University Press, Aberdeen, p 491-502

> Norman CP, Jones MB (1992) Influence of depth, season and moult stage on the diet of the velvet swimming crab Necora puber (Brachyura, Portunidae). Estuar Coast Shelf Sci 34:71-83

- Norman CP, Jones MB (1993) Reproductive ecology of the velvet swimming crab, Necora puber (Brachyura:Portunidae), at Plymouth. J Mar Biol Assoc UK 73:379-389

Pallas A, Garcia-Calvo B, Corgos A, Bernardez C, Freire J (2006) Distribution and habitat use patterns of benthic decapod crustaceans in shallow waters: a comparative approach. Mar Ecol Prog Ser 324:173-184

Pardo LM, Palma AT, Prieto C, Sepulveda P, Valdivia I, Ojeda FP (2007) Processes regulating early post-settlement habitat use in a subtidal assemblage of brachyuran decapods. J Exp Mar Biol Ecol 344:10-22

Paul RKG (1981) Natural diet, feeding and predatory activity of the crabs Callinectes arcuatus and C. toxotes (Decapoda, Brachyura, Portunidae). Mar Ecol Prog Ser 6:91-99

> Pihl L, Rosenberg R (1982) Production, abundance, and biomass of mobile epibenthic marine fauna in shallow waters, western Sweden. J Exp Mar Biol Ecol 57:273-301

Raffaelli D, Hawkins S (1996) Intertidal ecology. Chapman \& Hall, London

Rilov G, Schiel DR (2006a) Seascape-dependent subtidalintertidal trophic linkages. Ecology 87:731-744

> Rilov G, Schiel DR (2006b) Trophic linkages across seascapes: subtidal predators limit effective mussel recruitment in rocky intertidal communities. Mar Ecol Prog Ser 327:83-93

> Robles C (1987) Predator foraging characteristics and prey population structure on a sheltered shore. Ecology 68: 1502-1514

Robles C, Sweetnam D, Eminike J (1990) Lobster predation on mussels: shore level differences in prey vulnerability and predator preference. Ecology 71:1564-1577

> Robles CD, Alvarado MA, Desharnais RA (2001) The shifting balance of littoral predator-prey interaction in regimes of hydrodynamic stress. Oecologia 128:142-152

> Silva ACF, Boaventura DM, Flores A, Ré P, Hawkins SJ (2004) Rare predation by the intertidal crab Pachygrapsus marmoratus on the limpet Patella depressa. J Mar Biol Assoc UK 84:367-370 
Silva ACF, Hawkins SJ, Boaventura DM, Thompson RC (2008) Predation by small mobile aquatic predators regulates populations of the intertidal limpet Patella vulgata (L.). J Exp Mar Biol Ecol 367:259-265

Silva ACF, Brazão S, Hawkins SJ, Thompson RC, Boaventura D (2009) Abundance, population structure and claw morphology of the semi-terrestrial crab Pachygrapsus marmoratus (Fabricius, 1787) on shores of differing wave exposure. Mar Biol 156:2591-2599

Sokal RR, Rohlf FJ (1995) Biometry: the principles and practice of statistics in biological research. WH Freeman, New York, NY

Spooner EH, Coleman RA, Attrill MJ (2007) Sex differences in body morphology and multitrophic interactions involving the foraging behaviour of the crab Carcinus maenas. PSZN I: Mar Ecol 28:394-403

Stevens BG, Armstrong DA, Cusimano R (1982) Feeding habits of the dungeness crab Cancer magister as determined by the index of relative importance. Mar Biol 72: 135-145

Thompson RC, Jenkins SR, Bussel JA (2000) A method for recording predator-prey encounters between crabs and limpets using wax replicas. J Mar Biol Assoc UK 80: 633-638

Thompson RC, Norton TA, Hawkins SJ (2004) Physical stress

Editorial responsibility: Steven Morgan,

Bodega Bay, California, USA and biological control regulate the producer-consumer balance in intertidal biofilms. Ecology 85:1372-1382

Underwood AJ (1997) Experiments in ecology. Their logical design and interpretation using analysis of variance. Cambridge University Press, Cambridge

Vermeij GJ (1976) Interoceanic differences in vulnerability of shelled prey to crab predation. Nature 260:135-136

Warman CG, Reid DG, Nailor E (1993) Variation in the tidal migration behaviour and rhythmic light-responsiveness in the shore crab, Carcinus maenas. J Mar Biol Assoc UK 73: 355-364

Warner GF (1977) The biology of crabs. Elek Science, London

> Wear RG, Haddon M (1987) Natural diet of the crab Ovalipes catharus (Crustacea, Portunidae) around central and northern New Zealand. Mar Ecol Prog Ser 35:39-49

> Williams MJ (1981) Methods for analysis of natural diet in portunid crabs (Crustacea: Decapoda: Portunidae). J Exp Mar Biol Ecol 52:103-113

Williams MJ (1982) Natural food and feeding in the commercial sand crab Portunus pelagicus Linnaeus, 1766 (Crustacea: Decapoda: Portunidae) in Moreton Bay, Queensland. J Exp Mar Biol Ecol 59:165-176

> Yamada SB, Boulding EG (1998) Claw morphology, prey size selection and foraging efficiency in generalist and specialist shell-breaking crabs. J Exp Mar Biol Ecol 220:191-211

Submitted: August 12, 2009; Accepted: February 16, 2010

Proofs received from author(s): April 26, 2010 